\title{
Tibetan-Language Sources
}

\section{Testimony of $\mathrm{Ba}$}

\author{
BL fragment \\ DBA' 2000
}

RBA 2011.1

RBA 2011.2

SBA 1961.1-2

SBA 1962

SBA 1968

SBA 1980

SBA 1982.1-3

SBA 2009.1

SBA 2009.2
Or.8210/S. 9498(A-D) and Or.8210/S. 13683(C). Online on the IDP. http://idp.bl.uk/

“dba' bzhed.” In $\mathrm{dBa}$ ' bzhed: The Royal Narrative Concerning the Bringing of the Buddha's Doctrine to Tibet, edited by Pasang Wangdu and Hildegard Diemberger, 123-156. Vienna: Verlag der Österreichischen Akademie der Wissenschaften, 2000.

"rba bzhed." In Bod kyi lo rgyus rnam thar phyogs bsgrigs, edited by Dpal brtsegs bod yig dpe rnying zhib 'jug khang, vol. 36, 63-110. Zi ling: Mtsho sngon mi rigs dpe krun khang, 2011.

"rba bzhed." In Bod kyi lo rgyus rnam thar phyogs bsgrigs, edited by Dpal brtsegs bod yig dpe rnying zhib 'jug khang, vol. 36, 111-143. Zi ling: Mtsho sngon mi rigs dpe krun khang, 2011.

Stein, Rolf A., ed. Une Chronique ancienne de bSam-yas: sBa-bžed. Paris: Adrien-Maisonneuve, 1961.

Dpa' bo Gtsug lag phreng ba (Lokesh Chandra, ed.). Mkhas-pahii-dgah-ston of Dpah-bo-gtsuglag (also known as Lho-brag-chos-hbyun) Part 4 (ja). Delhi: International Academy of Indian Culture, 1962.

Stag lha phun tshogs bkra shis, ed. Btsan po khri srong lde btsan dang / mkhan po slob dpon padma`i dus mdo sngags so sor mdzad pa’i sba bzhed zhabs btags ma. Dharamsala: Shes rig par khang, 1968.

Dpa' bo Gtsug lag phreng ba. 1980. Chos 'byung mkhas pa'i dga' ston: A Detailed History of the Development of Buddhism in India and Tibet by the Second Dpa'-bo of Gnas-nan,, Gtsuglag-'phren-ba. Reproduced from Prints from the Lho-brag block from Rumtek Monastery. 2 vols. Delhi: Karmapae chodey gyalwae sungrab partun khang, 1980.

Mgon po rgyal mtshan, ed. Sba bzhed ces bya ba las sba gsal snang gi bzhed pa bzhugs. Beijing: Mi rigs dpe skrun khang, 1980/1982.

“rba bzhed.” In Rba bzhed phyogs bsgrigs, edited by Bde skyid, 80-158. Beijing: Mi rigs dpe skrun khang, 2009.

“chos 'byung gi yi ge zhib mo.” In Rba bzhed phyogs bsgrigs, edited by Bde skyid, 159-236. Beijing: Mi rigs dpe skrun khang, 2009.

\section{Dunhuang Documents}

The texts marked "IOL Tib J $n$ " or "Or. $n$ " in this volume come from the Dunhuang cave complex in Mogao, China, as do texts marked "Pelliot tibétain $n$." The former two types are now housed in the British Library, the latter in the Bibliothèque nationale de France. Images of most of these manuscripts can be found on the International Dunhuang Project website (http://idp.bl.uk), Gallica (https:// gallica.bnf.fr/) or Artstor (http://www.artstor.org/index. shtml).
IOL Tib J 321

IOL Tib J 370/6
The 'Phags pa thabs kyi zhags pa pad ma 'phreng gi don bsdus pa Mahāyoga text and commentary.

The Single Volume of Scriptures that Fell from Heaven account of (Khri) Srong brtsan and Khri Srong lde brtsan establishing the dharma in Tibet. 
IOL Tib J 466/3

IOL Tib J 480

IOL Tib J 597

IOL Tib J 598

IOL Tib J 689/2

IOL Tib J 723

IOL Tib J 731

IOL Tib J 739

IOL Tib J 750

IOL Tib J 1375

Or.8210/S. 9323

Or.8210/S. 9497

Or.8210/S. 9498(A-D)

Or.8210/S. 13683(C)

Or.8212/187

Or.15000/332

Pelliot tibétain 44

Pelliot tibétain 149

Pelliot tibétain 443

Pelliot tibétain 840/3

Pelliot tibétain 996

Pelliot tibétain 1051

Pelliot tibétain 1060

Pelliot tibétain 1064

Pelliot tibétain 1089

Pelliot tibétain 1096

Pelliot tibétain 1105

Pelliot tibétain 1109/2
A Tridandaka prayer paying homage to Buddhas, bodhisatva-s, Indian teachers and kings supporting the dharma, including Khri Srong lde brtsan.

Regulations for local Buddhist communities.

Copy of The Prophecy of the Khotanese Arhat found in IOL Tib J 598.

The Prophecy of the Khotanese Arhat.

A list of the succession of Spiritual Friends (dge ba'i bshes gnyen) of Bsam yas and 'Phrul snang temples.

An Old Tibetan poetic or ritual text.

The Tale of the Separation of the Horse and the Wild Ass narrative oriented towards funerary rites.

A text on dice divination.

Version I of the Old Tibetan Annals (+PT 1288), containing the years 672-747.

A fragment of the Old Tibetan Chronicle.

Fragments of Tibetan and Chinese text used as patches.

Paper fragment of a Chinese drawing of a deity.

The larger fragments of the BL Fragment (see above under: Testimony of $B a$ ).

The smaller fragments of the BL Fragment (see above under: Testimony of $B a$ )

Version II of the Old Tibetan Annals.

The So sor thar pa'i mdo (Prātimokșa Sūtra) fragment from Miran Fort.

An account of Padmasambhava's introduction of Phur pa teachings in Tibet and description of a Phur pa ritual.

The tale of the diffusion of the Ārya-bhadracaryā-pranidhāna teachings from India to Tibet. Invocation to Mahābala including spells.

A work recounting Khri Srong lde brtsan's introduction of tantra in Tibet and its subsequent gradual decline.

Nam ka'i snying po's lineage of Buddhist Chan masters, followed by the Mdo sde bgyad bcu khungs Tibetan Chan treatise.

A text on dice divination.

A ritual text related to horses that includes a catalogue of Tibetan principalities.

A manuscript containing a text on veterinary science and a text concerning domestic rules of the saingha.

A petition concerning the hierarchy of administrators' ranks around Dunhuang.

A judicial document concerning the loss or theft of a horse at a way-station.

Fragment of a text written on the verso of a scroll containing the Prajñāpāramitā Sūtra in eight thousand verses (小品般若波羅蜜經).

Damaged document containing the names of different goods. 
Pelliot tibétain 1122 Painting representing the Great King Vaiśravaṇa standing between two goddesses.

Pelliot tibétain 1128/2 A document related to taxation around Dunhuang.

Pelliot tibétain 1134/2 A narrative on the antecedent to certain funerary rites.

Pelliot tibétain 1136/1 The tale of securing a psychopomp horse, oriented towards funerary rites.

Pelliot tibétain 1144 A pothi manuscript containing a narrative connected to the Old Tibetan Chronicles.

Pelliot tibétain 1285 The account of a contest between Gshen and Bon priests.

Pelliot tibétain 1286 A genealogy related to the Old Tibetan Chronicle.

Pelliot tibétain 1287 The Old Tibetan Chronicle.

Pelliot tibétain 1288 Version I of the Old Tibetan Annals (+IOL Tib J 750).

Pelliot tibétain 1290 A fragmentary text containing information on the coronation of Khri Gtsug lde brtsan, principalities and way-stations. 


\section{Other Tibetan-Language Works}

Bde skyid, ed. 'Rba bzhed' phyogs bsgrigs / bde skyid kyis bsgrigs /. Beijing: Mi rigs dpe’i skrun khang, 2009.

Bis mdo Rdo rje rin chen. “'Sba bzhed' las 'byung ba'i don chen 'ga'i dogs dpyod." In Bod kyi yig rnying zhib 'jug, edited by Kha sgang Bkra shis tshe ring, 450-455. Beijing: Mi rigs dpe skrun khang, 2003.

Bod kyi lo rgyus rags rim g.yu yi phreng ba: see under Chab spel Tshe brtan phun tshogs.

Bod kyi lo rgyus rnam thar phyogs bsgrigs: see under Dpal brtsegs bod yig dpe rnying zhib 'jug khang, ed.

Bod kyi snga rabs dam pa rnams kyi gsungs chos phyag bris ma rin chen gser phreng: see under 'Brug thar and Karma bde legs, eds.

'Bri gung sKyabs mgon Che tshang. Tun hong bod kyi yig snying las byung ba / bod btsan po'i rgyal rabs. Dehradun: Songtsen Library, 2010.

'Brug thar and Karma bde legs, eds. Bod kyi snga rabs dam pa rnams kyi gsungs chos phyag bris ma rin chen gser phreng. Lanzhou: Kan su'u rig gnas dpe skrun khang, 2015.

Bsam yas rtsom pa: see under Span pa rdo rje.

Bsam yas dkar chag: see under Tshe ring don grub.

Bsod nams skyid. “Gna' bo'i bod kyi yig rnying las 'slung tshang' dang 'slungs dpon' zhes pa'i tha snyad la rags tsam dpyad pa." In Bod kyi yig rnying zhib 'jug, edited by Kha sgang Bkra shis tshe ring, 266-271. Beijing: Mi rigs dpe skrun khang, 2003.

Bu ston chos 'byung: Bu ston Rin chen grub. Chos kyi 'byung gnas gsung rab rin po che'i gter mdzod. In Gsung 'bum / rin chen grub, edited by Lokesh Chandra, vol. 24, 633-1055. New Delhi: Zhol bka' 'gyur par khang, 1965-1971.

Chab spel Tshe brtan phun tshogs, ed., Bod kyi lo rgyus rags rim g.yu yi phreng ba. 2 vols. Lhasa: Bod ljongs bod yig dpe rnying dpe skrun khang, 1989.

Chos 'byung me tog snying po: see under MTN.

Chos 'byung mkhas pa'i dga' ston: see under Mkhas pa'i dga' ston.

Chos kyi 'byung gnas gsung rab rin po che'i gter mdzod: see under Bu ston chos 'byung.

De bzhin gshegs pa'i gsang ba bsam gyis mi khyab pa bstan pa'i mdo. In Bka' 'gyur (Sde dge) vol. 39. Sde dge: Sde dge par khang chen mo, 1733.

Dba' bzhed (as 2010 publication): see under Longs khang Phun tshogs rdo rje.

Dbyangs can mtsho. “'Sba bzhed' kyi rtsom pa po dang de'i lo rgyus rig pa'i rin thang la dpyad pa." Krung go'i bod kyi shes rig/ China Tibetology 4 (1996): 79-86.

Dpa' bo Gtsug lag phreng ba: see under Mkhas pa'i dga' ston.

Dpal brtsegs bod yig dpe rnying zhib 'jug khang, ed. Bod kyi lo rgyus rnam thar phyogs bsgrigs. 120 volumes. Zi ling: Mtsho sngon mi rigs dpe skrun khang, 2010-2015.

Duojie, Dongzhi. "Ton hong gter yig las sba bzhed kyi shog hrul yi ge'i skor." Bod ljongs slob grwa chen mo'i rig deb /. Journal of Tibet University 4 (2012): 37-48.

Ga yā mgo'i ri'i mdo. In Bka' 'gyur (Sde dge) vol. 49. Sde dge: Sde dge par khang chen mo, 1733.

Gna' bo'i bod kyi yig rnying las 'slung tshang' dang 'slungs dpon' zhes pa'i tha snyad la rags tsam dpyad pa: see under Bsod nams skyid.

Kamalaśīla. Bsgom pa'i rim pa. In Bstan 'gyur (Sde dge), vol. 110. Delhi: Sde dge par khang, 1982-1985.
Lde'u Jo sras. Mkhas pa lde'us mdzad pa'i rgya bod kyi chos 'byung rgyas pa. In Rgya bod kyi chos 'byung pa. Lhasa: Bod ljongs mi dmangs dpe skrun khang, 1987.

Lho brag chos 'byung: see under Mkhas pa'i dga' ston.

Longs khang Phun tshogs rdo rje, ed. Dba' bzhed. Lhasa: Bod ljongs bod yig dpe rnying dpe skun khang, 2010.

MBNTH: 'Mi rje thas mdzad byang chub sems dpa' sems dpa' chen po chos rgyal mes dbon rnam gsum gyi rnam par thar pa rin po che'i phreng ba." In Rin chen gter mdzod chen po'i rgyab chos, vol. 7. Paro: Ugyan Tempai Gyaltsen, 1980.

Mdo sde dgongs pa nges 'grel (Ārya-samidhi-nirmocana-sūtra). In $B k a$ ' 'gyur (Sde dge), vol. 49. Sde dge: Sde dge par khang chen mo, 1733.

Mi rje lhas mdzad byang chub sems dpa' sems dpa' chen po chos rgyal mes dbon rnam gsum gyi rnam par thar pa rin po che' $i$ phreng ba: see under MBNTH.

Mkhas pa'i dga' ston 1962: Dpa' bo Gtsug lag phreng ba (Lokesh Chandra, ed.). Mkhas-pahi-dgah-ston of Dpah-bo-gtsug-lag (also known as Lho-brag-chos-ḥbyun) Part 4 (ja). New Delhi: International Academy of Indian Culture, 1962.

Mkhas pa'i dga' ston 1980: Dpa' bo Gtsug lag phreng ba. Chos 'byung mkhas pa'i dga' ston: A Detailed History of the Development of Buddhism in India and Tibet by the Second Dpa'-bo of Gnas-nan், Gtsug-lag-'phren-ba. Reproduced from Prints from the Lho-brag block from Rumtek Monastery. 2 vols. New Delhi: Delhi Karmapae Chodhey Gyalwae Sungrab Partun Khang, 1980.

MTN: Meisezahl, Richard O. Die große Geschichte des Tibetischen Buddhismus nach alter Tradition. Sankt Augustin: VGH Wissenschaftsverlag, 1985.

Padma dkar po. Phyag rgya chen po'i man ngag gi bshad sbyar rgyal ba'i gan mdzod. In Gsung 'bum Padma dkar po, vol. 21. Darjeeling: Kargyud sungrab nyamso khang, 1973-1974.

'Rba bzhed' phyogs bsgrigs: see under Bde skyid.

Rme ru Yul lha thar. "Sba bzhed kyi dpar gzhi'i skor dang des bod kyi lo rgyus rig gzhung la thebs pa'i shugs rkyen skor las 'phros pa'i gtam." Bod ljongs zhib 'jug 4 (2012): 85-92.

Sba bzhed kyi dpar gzhi'i skor dang des bod kyi lo rgyus rig gzhung la thebs pa'i shugs rkyen skor las 'phros pa'i gtam: see under Rme ru Yul lha thar.

'Sba bzhed' kyi rtsom pa po dang de'i lo rgyus rig pa'i rin thang la dpyad pa: see under Dbyangs can mtsho.

'Sba bzhed' las 'byung ba'i don chen 'ga'i dogs dpyod: see under Bis mdo Rdo rje rin chen.

Span pa rdo rje. Bsam yas rtsom pa. Sarnath, India: Central Institute of Higher Tibetan Studies, 2005.

Tshe ring don grub, ed. Bsam yas dkar chag. Gansu: Kan su'i mi rigs dpe skrun khang, 2009.

Ton hong gter yig las sba bzhed kyi shog hrul yi ge'i skor: see under Duojie, Dongzhi.

Tun hong bod kyi yig snying las byung ba / bod btsan po'i rgyal rabs: see under 'Bri gung sKyabs mgon Che tshang.

Zhu ston Nyi ma grag pa: see under Zhu yas nyi ma grags pas mdzad pa'i zhang bod kyi sgra bsdebs.

Zhu yas nyi ma grags pas mdzad pa'i zhang bod kyi sgra bsdebs, edited by Zhu ston Nyi ma grag pa. An undated xylograph held in digital form in the BDRC, under Resource ID W8LS16829. 